\title{
Testing Theories of American Politics: Elites, Interest Groups, and Average Citizens
}

\author{
Martin Gilens and Benjamin I. Page
}

\begin{abstract}
Each of four theoretical traditions in the study of American politics - which can be characterized as theories of Majoritarian Electoral Democracy, Economic-Elite Domination, and two types of interest-group pluralism, Majoritarian Pluralism and Biased Pluralism—offers different predictions about which sets of actors have how much influence over public policy: average citizens; economic elites; and organized interest groups, mass-based or business-oriented.

A great deal of empirical research speaks to the policy influence of one or another set of actors, but until recently it has not been possible to test these contrasting theoretical predictions against each other within a single statistical model. We report on an effort to do so, using a unique data set that includes measures of the key variables for 1,779 policy issues.

Multivariate analysis indicates that economic elites and organized groups representing business interests have substantial independent impacts on U.S. government policy, while average citizens and mass-based interest groups have little or no independent influence. The results provide substantial support for theories of Economic-Elite Domination and for theories of Biased Pluralism, but not for theories of Majoritarian Electoral Democracy or Majoritarian Pluralism.
\end{abstract}

W ho governs? Who really rules? To what extent is the broad body of U.S. citizens sovereign, semisovereign, or largely powerless? These questions have animated much important work in the study of American politics.

While this body of research is rich and variegated, it can loosely be divided into four families of theories: Majoritarian

A permanent link to supplementary materials provided by the authors precedes the References section.

Martin Gilens is Professor of Politics at Princeton University (milens@princeton.edu). His research examines representation, public opinion, and mass media, especially in relation to inequality and public policy. Professor Gilens is the author of Affluence \& Influence: Economic Inequality and Political Power in America (2012, Princeton University Press). Benjamin I. Page is Gordon S. Fulcher Professor of Decision Making at Northwestern University (b-page@northwestern.edu). His research interests include public opinion, policy making, the mass media, and U.S. foreign policy. He is currently engaged in a large collaborative project to study Economically Successful Americans and the Common Good. For helpful comments the authors are indebted to Larry Bartels and Jeff Isaac, to the anonymous reviewers from Perspectives on Politics, and to seminar participants at Harvard University and the University of Rochester.
Electoral Democracy, Economic-Elite Domination, and two types of interest-group pluralism-Majoritarian Pluralism, in which the interests of all citizens are more or less equally represented, and Biased Pluralism, in which corporations, business associations, and professional groups predominate. Each of these perspectives makes different predictions about the independent influence upon U.S. policy making of four sets of actors: the Average Citizen or "median voter," Economic Elites, and Mass-based or Business-oriented Interest Groups or industries.

Each of these theoretical traditions has given rise to a large body of literature. Each is supported by a great deal of empirical evidence-some of it quantitative, some historical, some observational-concerning the importance of various sets of actors (or, all too often, a single set of actors) in U.S. policy making. This literature has made important contributions to our understanding of how American politics works and has helped illuminate how democratic or undemocratic (in various senses) our policy making process actually is. Until very recently, however, it has been impossible to test the differing predictions of these theories against each other within a single statistical model that permits one to analyze the independent effects of each set of actors upon policy outcomes.

Here - in a tentative and preliminary way-we offer such a test, bringing a unique data set to bear on the problem. Our measures are far from perfect, but we hope that this first step 
will help inspire further research into what we see as some of the most fundamental questions about American politics.

The central point that emerges from our research is that economic elites and organized groups representing business interests have substantial independent impacts on U.S. government policy, while mass-based interest groups and average citizens have little or no independent influence. Our results provide substantial support for theories of Economic-Elite Domination and for theories of Biased Pluralism, but not for theories of Majoritarian Electoral Democracy or Majoritarian Pluralism.

In what follows, we briefly review the four theoretical traditions that form the framework for our analyses and highlight some of the most prominent empirical research associated with each. We then describe our data and measures and present our results. We conclude by discussing the implications of our work for understanding American democracy and by identifying some of the directions for future research that our findings suggest.

\section{Four Theoretical Traditions}

Each of the four theoretical traditions we are addressing has produced a body of literature much too vast to review in detail here. We can only allude to a few central pieces of work in each tradition. And we must acknowledge that a particular scholar's work does not always fall neatly into a single category. Some scholars work across - or independently of - our theoretical categories, embracing multiple influences and complex processes of policy making. Here we focus on ideal types of theory, for the purpose of outlining certain distinctive predictions that those types of theory tend to make. Given the nature of our data, we focus on the societal sources of influence that these theories posit, rather than on the mechanisms of influence that they discuss.

\section{Majoritarian Electoral Democracy}

Theories of majoritarian electoral democracy, as positive or empirical theories, attribute U.S. government policies chiefly to the collective will of average citizens, who are seen as empowered by democratic elections. Such thinking goes back at least to Tocqueville, who (during the Jacksonian era) saw American majorities as "omnipotent" - particularly at the state level —and worried about "tyranny of the majority." It is encapsulated in Abraham Lincoln's reference to government "of the people, by the people, for the people," and was labeled by Robert Dahl "populistic democracy."

An important modern incarnation of this tradition is found in rational choice theories of electoral democracy, in which vote-seeking parties or candidates in a two-party system tend to converge at the mid-point of citizens' policy preferences. If preferences are jointly single-peaked so that they can be arrayed along a single dimension, the "median voter theorem"- posited verbally by Harold Hotelling, proved by Duncan Black, and popularized by Anthony
Downs in his Economic Theory of Democracy—states that two vote-seeking parties will both take the same position, at the center of the distribution of voters' most-preferred positions. Under the relevant assumptions, public policy that fits the preferences of the median voter is not only the empirically-predicted equilibrium result of two-party electoral competition; as the "Condorcet winner" it also has the normative property of being the "most democratic" policy, in the sense that it would be preferred to any alternative policy in head-to-head majority-rule voting by all citizens. ${ }^{3}$

Subsequent "chaos" results by social choice theorists, starting with Kenneth Arrow, have indicated that the median voter prediction follows logically only for unidimensional politics. If citizens' preference orderings are not unidimensional and are sufficiently diverse, majority rule-hence also two-party electoral competition-might not lead to any equilibrium outcome at all. ${ }^{4}$ It is important to note, however, that what might theoretically happen will not necessarily ever happen in practice. Real-world outcomes depend upon how institutions are organized and how preferences are actually configured.

Despite the "chaos" results, and despite many criticisms of the median-voter theorem as simplistic and empirically inapplicable or wrong, ${ }^{5}$ a good many scholars-probably more economists than political scientists among themstill cling to the idea that the policy preferences of the median voter tend to drive policy outputs from the U.S. political system. A fair amount of empirical evidence has been adduced-by Alan Monroe; Benjamin Page and Robert Shapiro; Robert Erikson, Michael MacKuen, and James Stimson (authors of the very influential Macro Polity); and others- that seems to support the notion that the median voter determines the results of much or most policy making. This evidence indicates that U.S. federal government policy is consistent with majority preferences roughly two-thirds of the time; that public policy changes in the same direction as collective preferences a similar two-thirds of the time; that the liberalism or conservatism of citizens is closely associated with the liberalism or conservatism of policy across states; and that fluctuations in the liberal or conservative "mood" of the public are strongly associated with changes in the liberalism or conservatism of policy in all three branches of government. $^{6}$

The fly in the ointment is that none of this evidence allows for, or explicitly assesses, the impact of such variables as the preferences of wealthy individuals, or the preferences and actions of organized interest groups, which may independently influence public policy while perhaps being positively associated with public opinionthereby producing a spurious statistical relationship between opinion and policy.

Recent research by Larry Bartels and by one of the present authors (Gilens), which explicitly brings the preferences of "affluent" Americans into the analysis along 
with the preferences of those lower in the income distribution, indicates that the apparent connection between public policy and the preferences of the average citizen may indeed be largely or entirely spurious. ${ }^{7}$

The "electoral reward and punishment" version of democratic control through elections-in which voters retrospectively judge how well the results of government policy have satisfied their basic interests and values, and politicians enact policies in anticipation of judgments that they expect will later be made by what V.O. Key, Jr., called "latent" public opinion-might be thought to offer a different prediction: that policy will tend to satisfy citizens' underlying needs and values, rather than corresponding with their current policy preferences. ${ }^{8}$ We cannot test this prediction because we do not have-and cannot easily imagine how to obtain-good data on individuals' deep, underlying interests or values, as opposed to their expressed policy preferences. But the evidence that collective policy preferences are generally rather stable over time suggests that expressed collective policy preferences may not often diverge markedly from subsequently manifested "latent" preferences. They may do so only under special circumstances, such as economic recessions or disastrous wars. ${ }^{9}$ If so, the electoral-rewardand-punishment type of democratic theory, too, predicts that most of the time public policy will respond to the current policy preferences of the average citizen.

\section{Economic-Elite Domination}

A quite different theoretical tradition argues that U.S. policy making is dominated by individuals who have substantial economic resources, i.e., high levels of income or wealth-including, but not limited to, ownership of business firms.

Not all "elite theories" share this focus. Some emphasize social status or institutional position-such as the occupancy of key managerial roles in corporations, or top-level positions in political parties, in the executive, legislative, or judicial branches of government, or in the highest ranks of the military. Some elite theories postulate an amalgam of elites, defined by combinations of social status, economic resources, and institutional positions, who achieve a degree of unity through common backgrounds, coinciding interests, and social interactions.

For example, C. Wright Mills' important book, The Power Elite, offers a rather nuanced account of how U.S. social, economic, political, and military elites have historically alternated in different configurations of dominance. Mills noted that his elites derived in substantial proportions from the upper classes, including the very rich and corporate executives, but their elite status was not defined by their wealth. ${ }^{10}$ Our focus here is on theories that emphasize the policy-making importance of economic elites.

Analyses of U.S. politics centered on economic elites go back at least to Charles Beard, who maintained that a chief aim of the framers of the U.S. Constitution was to protect private property, favoring the economic interests of wealthy merchants and plantation owners rather than the interests of the then-majority small farmers, laborers, and craft workers. A landmark work in this tradition is G. William Domhoff's detailed account of how elites (working through foundations, think-tanks, and an "opinionshaping apparatus," as well as through the lobbyists and politicians they finance) may dominate key issues in U.S. policy making despite the existence of democratic elections. Philip A. Burch has exhaustively chronicled the economic backgrounds of federal government officials through American history. Thomas Ferguson's analysis of the political importance of "major investors" might be seen as a theory of economic elites. Most recently, Jeffrey Winters has posited a comparative theory of "Oligarchy," in which the wealthiest citizens_-even in a "civil oligarchy" like the United States-dominate policy concerning crucial issues of wealth and income protection. ${ }^{11}$

Our third and fourth theoretical traditions posit that public policy generally reflects the outcome of struggle among organized interest groups and business firms. ${ }^{12}$

\section{Majoritarian Pluralism}

The roots of what we can characterize as theories of "majoritarian" interest-group pluralism go back to James Madison's Federalist Paper No. 10, which analyzed politics in terms of "factions"-a somewhat fuzzy concept that apparently encompassed political parties and even popular majorities, as well as what we would today consider organized interest groups, business firms, and industrial sectors. Madison argued that struggles among the diverse factions that would be found in an extensive republic would lead to policies more or less representative of the needs and interests of the citizenry as a whole — or at least would tend to defeat "tyrannical" policies, including the much-feared issuance of inflationary paper money that might cater to local majority factions of farmerdebtors but would be costly to merchant creditors. ${ }^{13}$

In the twentieth century, Arthur Bentley's The Process of Government and then David Truman's monumental The Governmental Process put groups at the center of political analysis, laying out a detailed picture of how organized interest groups might get their way. Truman offered a comprehensive and still-interesting catalogue of lobbying techniques and other methods of group influence. He also added an ingenious gloss to Madison that tends to increase both the plausibility and the normative appeal of majoritarian interest-group pluralism: the assertion that all interests have at least a minimum of influence in group-dominated policy making, because policy makers must (in order to avoid subsequent punishment) heed all "potential" groups that would form if their interests were trampled upon. ${ }^{14}$

Robert Dahl's analysis of New Haven city politics was Madisonian or Truman-like in its insistence that many 
(all?) diverse interests were represented, though Dahl focused as much on active members of the general public as on organized groups. Dahl's analyses of American politics in terms of "polyarchy" or "pluralist democracy" also come close to our ideal type of majoritarian pluralist theory, since they imply that the wants or needs of the average citizen tend to be reasonably well served by the outcomes of interest-group struggle. Several contemporary analysts of interest-group politics likewise appear to accept (at least implicitly) a picture of group struggle that results in more or less majoritarian results. ${ }^{15}$

A major challenge to majoritarian pluralist theories, however, is posed by Mancur Olson's argument that collective action by large, dispersed sets of individuals with individually small but collectively large interests tends to be prevented by the "free rider" problem. Barring special circumstances (selective incentives, byproducts, coercion), individuals who would benefit from collective action may have no incentive to personally form or join an organized group. If everyone thinks this way and lets George do it, the job is not likely to get done. This reasoning suggests that Truman's "potential groups" may in fact be unlikely to form, even if millions of peoples' interests are neglected or harmed by government. Aware of the collective action problem, officials may feel free to ignore much of the population and act against the interests of the average citizen. $^{16}$

\section{Biased Pluralism}

Olson's argument points toward an important variant line of thinking within the pluralist tradition: theories of "biased" pluralism, which posit struggles among an unrepresentative universe of interest groups-characterized by E.E. Schattschneider as a heavenly chorus with an "upper-class accent," and more recently dubbed by Kay Lehman Schlozman, Sidney Verba, and Henry Brady an "unheavenly chorus." Theories of biased pluralism generally argue that both the thrust of interest-group conflict and the public policies that result tend to tilt toward the wishes of corporations and business and professional associations. ${ }^{17}$

Schattschneider suggested that policy outcomes vary with the "scope of conflict": for example, that businessoriented interest groups tend to prevail over ordinary citizens when the scope is narrow and visibility is low. Grant McConnell added the idea that the actual "constituencies" of policy implementers can consist of powerful groups. George Stigler (articulating what some economists have scorned as "Chicago Marxism") analyzed the politics of regulation in terms of biased pluralism: the capture of regulators by the regulated. Charles Lindblom outlined a number of ways-including the "privileged position" of business-in which business firms and their associations influence public policy. Thomas Ferguson has posited an "investment theory" of politics in which "major investors"-especially representatives of particular industrial sectors-fund political parties in order to get policies that suit their economic interests. Fred Block's "neo-Polanyian" analysis emphasizes groups. Jacob Hacker and Paul Pierson's analysis of "winner-take-all-politics," which emphasizes the power of the finance industry, can be seen as a recent contribution to the literature of biased pluralism. ${ }^{18}$

Marxist and neo-Marxist theories of the capitalist state hold that economic classes - and particularly the bourgeoisie, the owners of the means of production-dominate policy making and cause the state to serve their material interests. As the Communist Manifesto put it, "The bourgeoisie has . . . conquered for itself, in the modern representative State, exclusive political sway. The executive of the modern State is but a committee for managing the common affairs of the whole bourgeoisie." ${ }^{19}$ We cannot precisely test the predictions of such theories, because we lack good measures of policy preferences by economic class. (In Marxist theory, neither income nor wealth accurately signals class position.) We can note, however, that certain "instrumentalist" Marxist theories, including the important version put forth by Ralph Miliband, make predictions resembling those of theories of Biased Pluralism: that interest groups and corporations representing "large scale business" tend to prevail. ${ }^{20}$

As to empirical evidence concerning interest groups, it is well established that organized groups regularly lobby and fraternize with public officials, move through revolving doors between public and private employment, provide self-serving information to officials, draft legislation, and spend a great deal of money on election campaigns. ${ }^{21}$ Moreover, in harmony with theories of biased pluralism, the evidence clearly indicates that most interest groups and lobbyists represent business firms or professionals. Relatively few represent the poor or even the economic interests of ordinary workers, particularly now that the U.S. labor movement has become so weak. ${ }^{22}$

But do interest groups actually influence policy? Numerous case studies have detailed instances in which all but the most dedicated skeptic is likely to perceive interest-group influence at work. A leading classic remains Schattschneider's analysis of the 1928 enactment of the Smoot-Hawley tariff, an astounding orgy of porkbarrel politics. ${ }^{23}$ Still, many quantitatively-oriented political scientists seem to ignore or dismiss such non-quantitative evidence. There have also been some efforts (particularly during the Cold War era, when unflattering depictions of U.S. politics may have been thought unpatriotic) to demonstrate that interest groups have no influence on policy at all. Raymond Bauer, Ithiel Pool, and Lewis Anthony Dexter argued that business had little or no effect on the renewal of reciprocal trade authority. Lester Milbrath, having conducted interviews with lobbyists and members of Congress, rated lobbyists' influence as very low. 
More recently, Fred McChesney has made the ingenious argument that campaign contributions from interest groups may not represent quid pro quo bribery attempts by groups, but instead result from extortion by politicians who threaten to harm the groups' interests. ${ }^{24}$

Very few studies have offered quantitative evidence concerning the impact of interest groups based on a number of different public policies. Important exceptions include the work of Mark Smith and that of Frank Baumgartner, Jeffrey Berry, Marie Hojnacki, David Kimball, and Beth Leech. ${ }^{25}$

Mark Smith examined 2,364 "business unity" issuesover a period of four decades — on which the U.S. Chamber of Commerce (arguably a reasonable proxy for business groups as a whole, on this particular set of issues where most businesses agreed) took a public stand for or against. He then calculated six measures of the Chamber's annual rate of "success" at getting the action or inaction it favored from Congress. ${ }^{26}$ The Chamber's average success rate in terms of proportion of bills enacted or defeated appears to have been fairly high, ${ }^{27}$ but Smith did not argue that such success necessarily demonstrates influence. (A batting-average approach to influence would have to assume that standtaking is unrelated to expectations of success. Further, in order to gauge business's independent impact and avoid spurious results, data on stands taken by other actors would need to be included as well.) Instead, Smith devoted most of his effort to analyzing the over-time correlates of high or low success, such as variations in the public "mood" and in the partisan composition of Congress.

Frank Baumgartner and his colleagues, in their meticulous examination of 98 cases of congressional policy making in which interest groups were active, investigated whether the magnitude of group resources that were deployed was related to outcomes across those cases. In their multivariate analyses, Baumgartner et al. found a modest tendency for policy outcomes to favor the side that enjoyed greater resources (PAC contributions, lobbying expenditures, membership size, etc.). ${ }^{28}$

Prior to the availability of the data set that we analyze here, no one we are aware of has succeeded at assessing interest-group influence over a comprehensive set of issues, while taking into account the impact of either the public at large or economic elites-let alone analyzing all three types of potential influences simultaneously.

\section{Testing Theoretical Predictions}

What makes possible an empirical effort of this sort is the existence of a unique data set, compiled over many years by one of us (Gilens) for a different but related purpose: for estimating the influence upon public policy of "affluent" citizens, poor citizens, and those in the middle of the income distribution.

Gilens and a small army of research assistants ${ }^{29}$ gathered data on a large, diverse set of policy cases:
1,779 instances between 1981 and 2002 in which a national survey of the general public asked a favor/ oppose question about a proposed policy change. A total of 1,923 cases met four criteria: dichotomous pro/con responses, specificity about policy, relevance to federal government decisions, and categorical rather than conditional phrasing. Of those 1,923 original cases, 1,779 cases also met the criteria of providing income breakdowns for respondents, not involving a Constitutional amendment or a Supreme Court ruling (which might entail a quite different policy-making process), and involving a clear, as opposed to partial or ambiguous, actual presence or absence of policy change. These 1,779 cases do not constitute a sample from the universe of all possible policy alternatives (this is hardly conceivable), but we see them as particularly relevant to assessing the public's influence on policy. The included policies are not restricted to the narrow Washington "policy agenda." At the same time-since they were seen as worth asking poll questions about- they tend to concern matters of relatively high salience, about which it is plausible that average citizens may have real opinions and may exert some political influence. ${ }^{30}$

For each case, Gilens used the original survey data to assess responses by income level. In order to cope with varying income categories across surveys, he employed a quadratic logistic regression technique to estimate the opinions of respondents at the tenth income percentile (quite poor), the fiftieth percentile (median), and the ninetieth percentile (fairly affluent). ${ }^{31}$

Here we use these policy preference data to measureimperfectly, but, we believe, satisfactorily— two independent variables posited as major influences upon policy making in the theoretical traditions discussed above.

Policy preferences at the fiftieth income percentilethat is, the preferences of the median-income survey respondent-work quite well as measures of the preferences of the average citizen (or, more precisely, the median non-institutionalized adult American), which are central to theories of Majoritarian Electoral Democracy. ${ }^{32}$ In all cases in which the relationship between income and preferences is monotonic, and in all cases in which there is no systematic relationship at all between the two, the preferences of the median-income respondent are identical to those of the median-preference respondent. In the remaining cases the two are very close to each other. ${ }^{33}$

We believe that the preferences of "affluent" Americans at the ninetieth income percentile can usefully be taken as proxies for the opinions of wealthy or very-high-income Americans, and can be used to test the central predictions of Economic-Elite theories. To be sure, people at the ninetieth income percentile are neither very rich nor very elite; in 2012 dollars, Gilens' "affluent" respondents received only about $\$ 146,000$ in annual household income. To the extent that their policy preferences differ from those of average-income citizens, however, we would 
argue that there are likely to be similar but bigger differences between average-income citizens and the truly wealthy.

Some evidence for this proposition comes from the 2011 Cooperative Congressional Election Study. ${ }^{34}$ Based on 13 policy-preference questions asked on this survey, the preferences of the top 2 percent of income earners (a group that might be thought "truly wealthy") are much more highly correlated with the preferences of the top 10 percent of earners than with the preferences of the average survey respondent $\left(r=.91\right.$ versus .69). ${ }^{35}$ Thus, the views of our moderately high-income "affluent" respondents appear to capture useful information about the views of the truly wealthy.

In any case, the imprecision that results from use of our "affluent" proxy is likely to produce underestimates of the impact of economic elites on policy making. If we find substantial effects upon policy even when using this imperfect measure, therefore, it will be reasonable to infer that the impact upon policy of truly wealthy citizens is still greater. $^{36}$

In order to measure interest-group preferences and actions, we would ideally like to use an index of the sort that Baumgartner and his colleagues developed for their ninety-eight policy issues: an index assessing the total resources brought to bear by all major interest groups that took one side or the other on each of our 1,779 issues. But it is not feasible to construct such an index for all our cases; this would require roughly twenty times as much work as did the major effort made by the Baumgartner research team on their cases. Fortunately, however, Baumgartner et al. found that a simple proxy for their index-the number of reputedly "powerful" interest groups (from among groups appearing over the years in Fortune magazine's "Power 25" lists) that favored a given policy change, minus the number that opposed itcorrelated quite substantially in their cases with the full interest-group index $(\mathrm{r}=0.73) .{ }^{37}$

Gilens, using a modified version of this simple count of the number of "powerful" interest groups favoring (minus those opposing) each proposed policy change, developed a measure of Net Interest Group Alignment. To the set of groups on the "Power 25" lists (which seemed to neglect certain major business interests) he added ten key industries that had reported the highest lobbying expenditures. (For the final list of included industries and interest groups, refer to Appendix 1.) For each of the 1,779 instances of proposed policy change, Gilens and his assistants drew upon multiple sources to code all engaged interest groups as "strongly favorable," "somewhat favorable," "somewhat unfavorable," or "strongly unfavorable" to the change. He then combined the numbers of groups on each side of a given issue, weighting "somewhat" favorable or somewhat unfavorable positions at half the magnitude of "strongly" favorable or strongly unfavorable positions. In order to allow for the likelihood of diminishing returns as the net number of groups on a given side increases (an increase from 10 to 11 groups likely matters less than a jump from 1 to 2 does), he took the logarithms of the number of pro groups and the number of con groups before subtracting. Thus,

Net Interest-Group Alignment $=\ln \left(\#\right.$ Strongly Favor $+\left[0.5^{*} \#\right.$ Somewhat Favor $]+1)-\ln \left(\#\right.$ Strongly Oppose $+\left[0.5^{*}\right.$ \# Somewhat Oppose] +1$)^{38}$

We also report here results for comparable group alignment indices that were computed separately for the mass-based and for the business-oriented sets of groups listed in Appendix 1.

Our dependent variable is a measure of whether or not the policy change proposed in each survey question was actually adopted within four years after the question was asked. (It turns out that most of the action occurred within two years). Of course there was nothing easy about measuring the presence or absence of policy change for each of 1,779 different cases; Gilens and his research assistants spent many hours poring over news accounts, government data, Congressional Quarterly publications, academic papers and the like. ${ }^{39}$

In order to test among our theoretical traditions, we begin by considering all organized interest groups together, not distinguishing between mass-based and business-oriented groups. Within a single statistical model, we estimate the independent impact upon our dependent variable (policy change) of each of three independent variables: the average citizen's policy preferences (preferences at the fiftieth income percentile); the policy preferences of economic elites (measured by policy preferences at the ninetieth income percentile); and the stands of interest groups (the Net Interest-Group Alignment Index).

Later, in order to distinguish clearly between Majoritarian Pluralism and Biased Pluralism, we will use two separate measures of net interest-group alignment, one involving only mass-based interest groups and the other limited to business and professional groups. The main hypotheses of interest, summarized in table 1 , follow fairly straightforwardly from our discussion of our four ideal types of theory.

In their pure form, theories of Majoritarian Electoral Democracy (for example, rational models of electoral competition that include no societal actors other than average citizens), predict that the influence upon policy of average citizens is positive, significant, and substantial, while the influence of other actors is not.

Theories of Economic-Elite Domination predict positive, significant, and substantial influence upon policy by economic elites. Most such theories allow for some (though not much) independent influence by average citizens, e.g., on non-economic social issues. Many also 


\begin{tabular}{|c|c|c|c|c|c|}
\hline \multirow[b]{2}{*}{ Theory (ideal type) } & \multicolumn{5}{|c|}{ Sets of Actors } \\
\hline & $\begin{array}{l}\text { Average } \\
\text { Citizens }\end{array}$ & $\begin{array}{l}\text { Economic } \\
\text { Elites }\end{array}$ & $\begin{array}{l}\text { All Interest } \\
\text { Groups }\end{array}$ & $\begin{array}{l}\text { Mass Interest } \\
\text { Groups }\end{array}$ & $\begin{array}{c}\text { Business Interest } \\
\text { Groups }\end{array}$ \\
\hline $\begin{array}{l}\text { Majoritarian Electoral } \\
\text { Democracy }\end{array}$ & $\mathrm{Y}$ & $\mathrm{n}$ & $\mathrm{n}$ & $\mathrm{n}$ & $\mathrm{n}$ \\
\hline $\begin{array}{l}\text { Dominance by Economic } \\
\text { Elites }\end{array}$ & y & $\mathrm{Y}$ & y & $n$ & y \\
\hline Majoritarian Pluralism & $\mathrm{y}$ & $\mathrm{n}$ & $\mathrm{Y}$ & $\mathrm{Y}$ & Y \\
\hline Biased Pluralism & $\mathrm{n}$ & $\mathrm{n}$ & y & y & $\mathrm{Y}$ \\
\hline \multicolumn{6}{|c|}{$\mathrm{n}=$ little or no independent influence } \\
\hline \multicolumn{6}{|c|}{$y=$ some independent influence } \\
\hline \multicolumn{6}{|c|}{$Y=$ substantial independent influence } \\
\hline
\end{tabular}

allow for some independent influence by business interest groups-and therefore probably by interest groups taken as a whole-though their emphasis is on wealthy individuals.

In general, theories of interest-group pluralism predict that only organized interest groups will have positive, significant, and substantial effects upon public policy. Influence proceeds from groups, not from wealthy (or other) individuals. Depending upon the type of pluralist theory, average citizens may or may not be well represented through organized groups, but they do not have a great deal of independent influence on their own.

Theories of Majoritarian Pluralism predict that the stands of organized interest groups, all taken together, rather faithfully represent (that is, are positively and substantially correlated with) the preferences of average citizens. But since most political influence proceeds through groups, a multivariate analysis that includes both interest-group alignments and citizens' preferences should show far more independent influence by the groups than the citizens. Truman's idea of "potential groups" does, however, leave room for some direct influence by average citizens.

Theories of Biased Pluralism, too, see organized interest groups as having much more influence than average citizens or individual economic elites. But they predict that business-oriented groups play the major role.

Recognizing the complexity of the political world, we must also acknowledge the possibility that more than one of these theoretical traditions has some truth to it: that several — even all—of our sets of actors may have substantial, positive, independent influence on public policy. And we must consider the null hypothesis that none of these theoretical traditions correctly describes even part of what goes on in American politics.

\section{Influence upon Policy of Average Citizens, Economic Elites, and Interest Groups}

Before we proceed further, it is important to note that even if one of our predictor variables is found (when controlling for the others) to have no independent impact on policy at all, it does not follow that the actors whose preferences are reflected by that variable - average citizens, economic elites, or organized interest groups of one sort or another-always "lose" in policy decisions. Policy making is not necessarily a zero-sum game among these actors. When one set of actors wins, others may win as well, if their preferences are positively correlated with each other.

It turns out, in fact, that the preferences of average citizens are positively and fairly highly correlated, across issues, with the preferences of economic elites (refer to table 2). Rather often, average citizens and affluent citizens (our proxy for economic elites) want the same things from government. This bivariate correlation affects how we should interpret our later multivariate findings in terms of "winners" and "losers." It also suggests a reason why serious scholars might keep adhering to both the Majoritarian Electoral Democracy and the Economic-Elite Domination theoretical traditions, even if one of them may be dead wrong in terms of causal impact. Ordinary citizens, for example, might often be observed to "win" (that is, to get their preferred policy outcomes) even if they had no independent effect whatsoever on policy making, if elites (with whom they often agree) actually prevail.

But net interest-group stands are not substantially correlated with the preferences of average citizens. Taking all interest groups together, the index of net interest-group alignment correlates only a non-significant .04 with average citizens' preferences! (Refer to table 2.) This casts grave doubt on David Truman's and others' argument that 
Table 2

Correlations among independent variables

\begin{tabular}{|c|c|c|c|c|c|}
\hline & $\begin{array}{c}\text { Average citizens' } \\
\text { preferences }\end{array}$ & $\begin{array}{l}\text { Economic elites' } \\
\text { preferences }\end{array}$ & $\begin{array}{l}\text { All interest } \\
\text { groups }\end{array}$ & $\begin{array}{c}\text { Mass public } \\
\text { interest groups }\end{array}$ & $\begin{array}{c}\text { Business } \\
\text { interest groups }\end{array}$ \\
\hline $\begin{array}{l}\text { Average citizens' } \\
\text { preferences }\end{array}$ & 一 & & & & \\
\hline $\begin{array}{l}\text { Economic elites' } \\
\text { preferences }\end{array}$ & $.78^{* * *}$ & 一 & & & \\
\hline All interest groups & .04 & .05 & - & & \\
\hline $\begin{array}{l}\text { Mass public } \\
\text { interest groups }\end{array}$ & $.12^{\star \star \star}$ & .01 & $.47^{\star \star \star}$ & 一 & \\
\hline $\begin{array}{l}\text { Business interest } \\
\text { groups }\end{array}$ & $-.10^{\star \star \star}$ & -.02 & $.96^{\star \star \star}$ & -.05 & - \\
\hline
\end{tabular}

${ }^{* * *} \mathrm{p}<.001 ; \mathrm{n}=1779$.

Note: Entries are correlation coefficients corrected for measurement error as explained in Appendix 2.

organized interest groups tend to do a good job of representing the population as a whole. Indeed, as table 2 indicates, even the net alignments of the groups we have categorized as "mass-based" correlate with average citizens' preferences only at the very modest (though statistically significant) level of .12.

Some particular U.S. membership organizationsespecially the AARP and labor unions - do tend to favor the same policies as average citizens. But other membership groups take stands that are unrelated (pro-life and pro-choice groups) or negatively related (gun owners) to what the average American wants. ${ }^{40}$ Some membership groups may reflect the views of corporate backers or their most affluent constituents. Others focus on issues on which the public is fairly evenly divided. Whatever the reasons, all mass-based groups taken together simply do not add up, in aggregate, to good representatives of the citizenry as a whole. Business-oriented groups do even worse, with a modest negative over-all correlation of -.10.

Nor do we find an association between the preferences of economic elites and the alignments of either massbased or business-oriented groups. The latter finding, which surprised us, may reflect profit-making motives among businesses as contrasted with broader ideological views among elite individuals. For example, economic elites tend to prefer lower levels of government spending on practically everything, while business groups and specific industries frequently lobby for spending in areas from which they stand to gain. Thus pharmaceutical, hospital, insurance, and medical organizations have lobbied for more spending on health care; defense contractors for weapons systems; the American Farm Bureau for agricultural subsidies, and so on.

\section{Initial Tests of Influences on Policy Making}

The first three columns of table 3 report bivariate results, in which each of three independent variables (taking all interest groups together, for now) is modeled separately as the sole predictor of policy change. Just as previous literature suggests, each of three broad theoretical traditions-Majoritarian Electoral Democracy, EconomicElite Domination, and interest-group pluralism—seems to gain support. When taken separately, each independent variable - the preferences of average citizens, the preferences

\section{Table 3}

\begin{tabular}{|c|c|c|c|c|}
\hline & Model 1 & Model 2 & Model 3 & Model 4 \\
\hline $\begin{array}{l}\text { Preferences } \\
\text { of average } \\
\text { citizens }\end{array}$ & $\begin{array}{l}.64 \\
(.08)^{\star \star \star}\end{array}$ & - & - & $\begin{array}{c}.03 \\
(.08)\end{array}$ \\
\hline $\begin{array}{l}\text { Preferences } \\
\text { of } \\
\text { economic } \\
\text { elites }\end{array}$ & - & $\begin{array}{l}.81 \\
(.08)^{\star \star \star}\end{array}$ & - & $\begin{array}{l}.76 \\
(.08)^{\star \star \star}\end{array}$ \\
\hline $\begin{array}{l}\text { Alignment of } \\
\text { interest } \\
\text { groups }\end{array}$ & - & - & $\begin{array}{l}.59 \\
(.09)^{\star \star \star}\end{array}$ & $\begin{array}{l}.56 \\
(.09)^{\star \star \star}\end{array}$ \\
\hline$R-s q$ & .031 & .049 & .028 & .074 \\
\hline
\end{tabular}

Note: All predictors are scaled to range from 0 to 1 . The dependent variable is the policy outcome, coded 1 if the proposed policy change took place within four years of the survey date and 0 if it did not. Predictors are the logits of the imputed percent of respondents at the fiftieth ("average citizens") or ninetieth ("economic elites") income percentile that favor the proposed policy change, and the Net InterestGroup Alignment Index described in the text. Standard errors are asymptotically distribution-free, and all analyses reflect estimated measurement error in the predictors, as described in Appendix 2. The standardized coefficients for model 4 in this table are $.01, .21$, and .16 for average citizens, economic elites, and interest groups, respectively. $\mathrm{N}=1,779$. 
of economic elites, and the net alignments of organized interest groups-is strongly, positively, and quite significantly related to policy change. Little wonder that each theoretical tradition has its strong adherents.

But the picture changes markedly when all three independent variables are included in the multivariate Model 4 and are tested against each other. The estimated impact of average citizens' preferences drops precipitously, to a non-significant, near-zero level. Clearly the median citizen or "median voter" at the heart of theories of Majoritarian Electoral Democracy does not do well when put up against economic elites and organized interest groups. The chief predictions of pure theories of Majoritarian Electoral Democracy can be decisively rejected. Not only do ordinary citizens not have uniquely substantial power over policy decisions; they have little or no independent influence on policy at all.

By contrast, economic elites are estimated to have a quite substantial, highly significant, independent impact on policy. This does not mean that theories of Economic-Elite Domination are wholly upheld, since our results indicate that individual elites must share their policy influence with organized interest groups. Still, economic elites stand out as quite influential-more so than any other set of actors studied here-in the making of U.S. public policy.

Similarly, organized interest groups (all taken together, for now) are found to have substantial independent influence on policy. Again, the predictions of pure theories of interest-group pluralism are not wholly upheld, since organized interest groups must share influence with economically-elite individuals. But interest-group alignments are estimated to have a large, positive, highly significant impact upon public policy.

These results suggest that reality is best captured by mixed theories in which both individual economic elites and organized interest groups (including corporations, largely owned and controlled by wealthy elites) play a substantial part in affecting public policy, but the general public has little or no independent influence.

The rather low explanatory power of all three independent variables taken together (with an R-squared of just .074 in Model 4) may partly result from the limitations of our proxy measures, particularly with respect to economic elites (since our "affluent" proxy is admittedly imperfect) and perhaps with respect to interest groups (since only a small fraction of politically-active groups are included in our measure). Again, the implication of these limitations in our data is that interest groups and economic elites actually wield more policy influence than our estimates indicate. But it is also possible that there may exist important explanatory factors outside the three theoretical traditions addressed in this analysis. Or there may be a great deal of idiosyncrasy in policy outputs, or variation across kinds of issues, that would be difficult for any general model to capture. With our present data we cannot tell.

The magnitudes of the coefficients reported in table 3 are difficult to interpret because of our transformations of the independent variables. A helpful way to assess the relative influence of each set of actors is to compare how the predicted probability of policy change alters when moving from one point to another on their distributions of policy dispositions, while holding other actors' preferences constant at their neutral points (50 percent favorable for average citizens and for economic elites, and a net interestgroup alignment score of 0 ). These changing probabilities, based on the coefficients in model 4 of table 3 , are linegraphed in figure 1 along with bar graphs of the underlying preference distributions.

Clearly, when one holds constant net interest-group alignments and the preferences of affluent Americans, it makes very little difference what the general public thinks. The probability of policy change is nearly the same (around 0.3) whether a tiny minority or a large majority of average citizens favor a proposed policy change (refer to the top panel of figure 1).

By contrast-again with other actors held constanta proposed policy change with low support among economically-elite Americans (one out of five in favor) is adopted only about 18 percent of the time, while a proposed change with high support (four out of five in favor) is adopted about 45 percent of the time. Similarly, when support for policy change is low among interest groups (with five groups strongly opposed and none in favor) the probability of that policy change occurring is only .16 , but the probability rises to .47 when interest groups are strongly favorable (refer to the bottom two panels of figure 1). ${ }^{41}$

When both interest groups and affluent Americans oppose a policy it has an even lower likelihood of being adopted (these proposed policies consist primarily of tax increases). At the other extreme, high levels of support among both interest groups and affluent Americans increases the probability of adopting a policy change, but a strong status quo bias remains evident. Policies with strong support (as defined above) among both groups are only adopted about 56 percent of the time (strongly favored policies in our data set that failed include proposed cuts in taxes, increases in tax exemptions, increased educational spending for $\mathrm{K}-12$, college support, and proposals during the Clinton administration to add a prescription drug benefit to Medicare).

\section{Majoritarian Electoral Democracy}

What are we to make of findings that seem to go against volumes of persuasive theorizing and much quantitative research, by asserting that the average citizen or the "median voter" has little or no independent influence on public policy?

As noted, our evidence does not indicate that in U.S. policy making the average citizen always loses out. Since 


\section{Figure 1 \\ Predicted probability of policy adoption (dark lines, left axes) by policy disposition; the distribution of preferences (gray columns, right axes)}

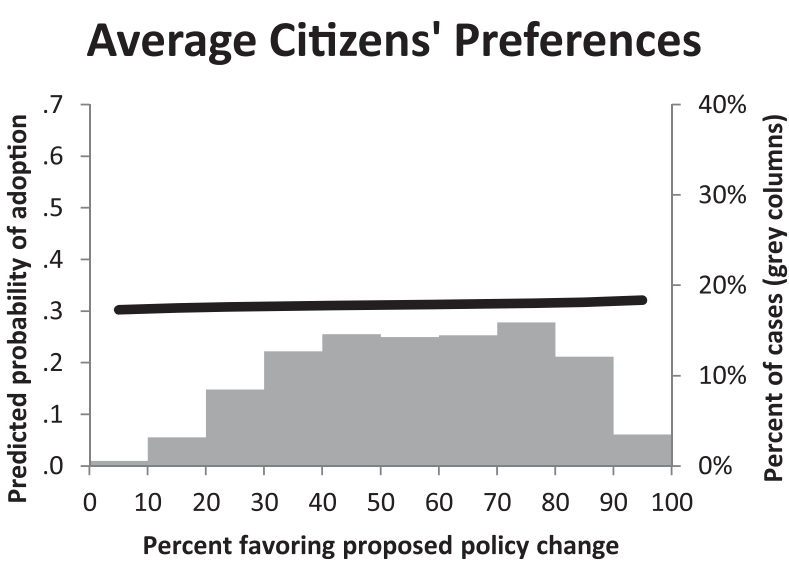

Economic Elites' Preferences

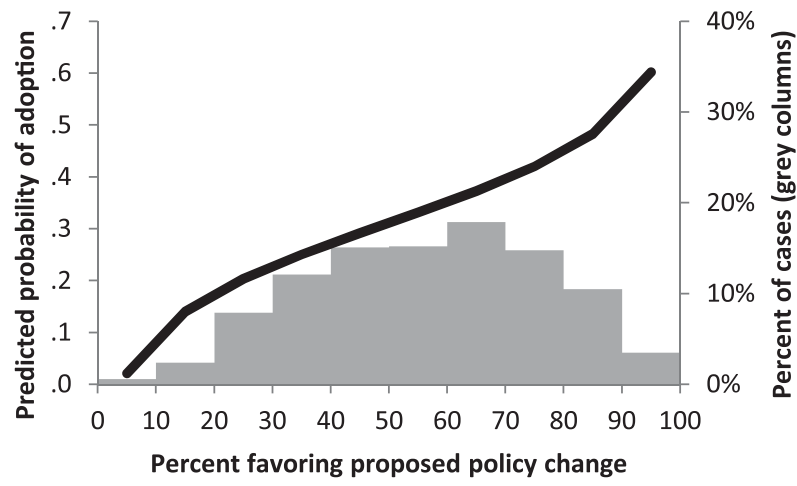

Interest Group Alignments

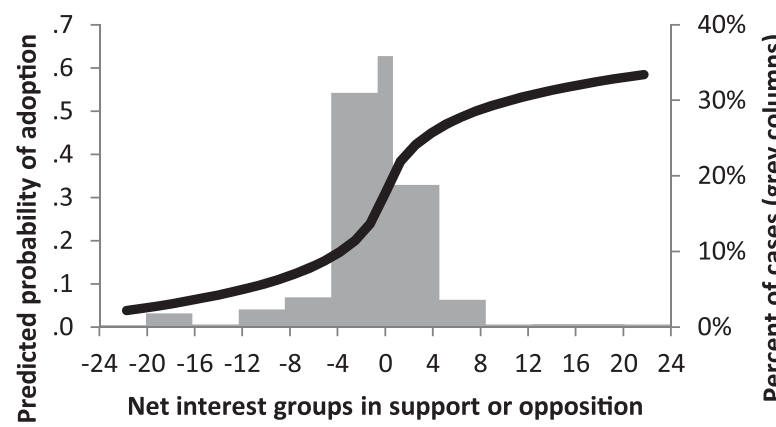

the preferences of ordinary citizens tend to be positively correlated with the preferences of economic elites, ordinary citizens often win the policies they want, even if they are more or less coincidental beneficiaries rather than causes of the victory. There is not necessarily any contradiction at all between our findings and past bivariate findings of a roughly two-thirds correspondence between actual policy and the wishes of the general public, or of a close correspondence between the liberal/conservative "mood" of the public and changes in policy making. ${ }^{42}$ Our main point concerns causal inference: if interpreted in terms of actual causal impact, the prior findings appear to be largely or wholly spurious.

Further, the issues about which economic elites and ordinary citizens disagree reflect important matters, including many aspects of trade restrictions, tax policy, corporate regulation, abortion, and school prayer, so that the resulting political losses by ordinary citizens are not trivial. Moreover, we must remember that in our analyses the preferences of the affluent are serving as proxies for those of truly wealthy Americans, who may well have more political clout than the affluent, and who tend to have policy preferences that differ more markedly from those of the average citizens. Thus even rather slight measured differences between preferences of the affluent and the median citizen may signal situations in which economic-elites want something quite different from most Americans and they generally get their way.

A final point: Even in a bivariate, descriptive sense, our evidence indicates that the responsiveness of the U.S. political system when the general public wants government action is severely limited. Because of the impediments to majority rule that were deliberately built into the U.S. political system-federalism, separation of powers, bicameralism-together with further impediments due to anti-majoritarian congressional rules and procedures, the system has a substantial status quo bias. Thus when popular majorities favor the status quo, opposing a given policy change, they are likely to get their way; but when a majority—even a very large majority—of the public favors change, it is not likely to get what it wants. In our 1,779 policy cases, narrow pro-change majorities of the public got the policy changes they wanted only about 30 percent of the time. More strikingly, even overwhelmingly large pro-change majorities, with 80 percent of the public favoring a policy change, got that change only about 43 percent of the time.

In any case, normative advocates of populistic democracy may not be enthusiastic about democracy by coincidence, in which ordinary citizens get what they want from government only when they happen to agree with elites or interest groups that are really calling the shots. When push comes to shove, actual influence matters.

\section{Economic Elites}

Economic-Elite Domination theories do rather well in our analysis, even though our findings probably understate the political influence of elites. Our measure of the preferences of wealthy or elite Americans - though 
useful, and the best we could generate for a large set of policy cases-is probably less consistent with the relevant preferences than are our measures of the views of ordinary citizens or the alignments of engaged interest groups. Yet we found substantial estimated effects even when using this imperfect measure. The real-world impact of elites upon public policy may be still greater.

What we cannot do with these data is distinguish definitively among different versions of elite theories. We cannot be sure whether we are capturing the political influence of the wealthiest Americans (the top 1 percent of wealth-holders? the top one-tenth of 1 percent?), or, conceivably, the less affluent but more numerous citizens around the ninetieth income percentile whose preferences are directly gauged by our measure.

In any case, we need to reiterate that our data concern economic elites. Income and wealth tend to be positively correlated with other dimensions of elite status, such as high social standing and the occupancy of high-level institutional positions, but they are not the same thing. We cannot say anything directly about the non-economic aspects of certain elite theories, especially those that emphasize actors who may not be highly paid, such as public officials and political party activists.

\section{Organized Interest Groups}

Our findings of substantial influence by interest groups is particularly striking because little or no previous research has been able to estimate the extent of group influence while controlling for the preferences of other key nongovernmental actors. Our evidence clearly indicates that-controlling for the influence of both the average citizen and economic elites-organized interest groups have a very substantial independent impact upon public policy. Theories of interest-group pluralism gain a strong measure of empirical support.

Here, too, the imperfections of our measure of interest-group alignment (though probably less severe than in the case of economically-elite individuals) suggest, a fortiori, that the actual influence of organized groups may be even greater than we have found. If we had data on the activity of the thousands of groups not included in our net interest-group alignment measure, we might find many cases in which a group (perhaps unopposed by any other groups) got its way. This might be particularly true of narrow issues like special tax breaks or subsidies aimed at just one or two business firms, which are underrepresented in our set of relatively highsalience policies. (Our data set includes only policies thought to be important enough for a national opinion survey to ask a question about it.)

An important feature of interest group influence is that it is often deployed against proposed policy changes. On the 1,357 proposed policy changes for which at least one interest group was coded as favoring or opposing change, in only 36 percent of the cases did most groups favor change, while in 55 percent of the cases most groups opposed change. (The remaining cases involved equal numbers for and against. ${ }^{43}$

\section{Distinguishing between Majoritarian Pluralism and Biased Pluralism}

Can we say anything further about whether processes of interest-group influence more closely resemble Trumanlike, broadly representative Majoritarian Pluralism, or Schattschneider-style "Biased" Pluralism, in which business interests, professional associations, and corporations play the dominant part?

We have already reported several findings that cast serious doubt upon Majoritarian Pluralism. If the net results of interest-group struggle were to help average citizens get their way-with organized groups perhaps representing citizens more effectively than politicallyinattentive Americans could do for themselves-we would expect that the net alignment of interest groups would be positively and strongly correlated with the policy preferences of the average citizen. But we know from table 2 that they are not in fact significantly correlated at all. Interestgroup alignments are almost totally unrelated to the preferences of average citizens. Moreover, there is no indication that officials' anticipation of reactions from "potential groups" brings policies in line with what citizens want. ${ }^{44}$ Empirical support for Majoritarian Pluralism looks very shaky, indeed. We also know that the composition of the U.S. interest-group universe is heavily tilted toward corporations and business and professional associations. ${ }^{45}$ This fact certainly points toward Biased rather than Majoritarian Pluralism.

To go a step further, theories of Majoritarian Pluralism predict relatively more independent influence upon policy by mass-based interest groups than do theories of Biased Pluralism. It may be useful, therefore, to distinguish between mass-based and business-oriented interest groups and to investigate how much policy influence each group actually has.

Accordingly, we computed separate net-interest-groupalignment indices for business-oriented and for massbased groups (refer to Appendix 1 for lists of each) and included both of them in a new multivariate analysis, along with the preferences of average citizens and economic elites-dropping our previous measure of the net alignment of all interest groups.

The results of this analysis are given in table 4. Clearly the predictions of Biased Pluralism theories fare substantially better than those of Majoritarian Pluralism theories. The influence coefficients for both mass-based and business-oriented interest groups are positive and highly significant statistically, but the coefficient for business groups is nearly twice as large as that for the mass groups. 


\begin{tabular}{|c|c|}
\hline Average citizens' preferences & $\begin{array}{l}.05 \\
(.08)\end{array}$ \\
\hline Economic elites' preferences & $\begin{array}{l}.78 \\
(.08)^{\star * *}\end{array}$ \\
\hline Mass-based interest groups & $\begin{array}{l}.24 \\
(.07)^{\star \star \star}\end{array}$ \\
\hline Business interest groups & $\begin{array}{l}.43 \\
(.08)^{\star \star \star}\end{array}$ \\
\hline R-sq & .07 \\
\hline \multicolumn{2}{|l|}{${ }^{* * *} p<.001$} \\
\hline \multicolumn{2}{|c|}{$\begin{array}{l}\text { Note: All predictors are scaled to range from } 0 \text { to } 1 \text {. } \\
\text { The dependent variable is the policy outcome, coded } 1 \text { if } \\
\text { the proposed policy change took place within four years of the } \\
\text { survey date and } 0 \text { if it did not. Predictors are the logits of } \\
\text { the imputed percent of respondents at the fiftieth ("average } \\
\text { citizens") or ninetieth ("economic elites") income percentile } \\
\text { that favor the proposed policy change, and the Net Interest- } \\
\text { Group Alignment Indices described in the text. Standard errors } \\
\text { are asymptotically distribution-free, and all analyses reflect } \\
\text { estimated measurement error in the predictors, as described in } \\
\text { Appendix } 2 . N=1,779 \text {. }\end{array}$} \\
\hline
\end{tabular}

Moreover, when we restricted this same analysis to the smaller set of issues upon which both types of groups took positions - that is, when we considered only cases in which business-based and mass-based interest groups were directly engaged with each other-the contrast between the estimated impact of the two types of groups was even greater. ${ }^{46}$

The advantage of business-oriented groups in shaping policy outcomes reflects their numerical advantage within the interest-group universe in Washington, and also the infrequency with which business groups are found simultaneously on both sides of a proposed policy change. ${ }^{47}$ Both these factors (numerical dominance and relative cohesion) play a part in the much stronger correlation of the overall interest-group alignment index with business groups than with mass-oriented groups $(.96$ versus .47, table 2). The importance of business groups' numerical advantage is also revealed when we rescale our measures of business and mass-oriented interest-group alignments to reflect the differing number of groups in each of these categories. Using this rescaled measure, a parallel analysis to that in table 4 shows that on a group-for-group basis the average individual business group and the average mass-oriented group appears to be about equally influential. The greater total influence of business groups in our analysis results chiefly from the fact that more of them are generally engaged on each issue (roughly twice as many, on average), not that a single business-oriented group has more clout on average than a single mass-based group. ${ }^{48}$
Taken as a whole, then, our evidence strongly indicates that theories of Biased Pluralism are more descriptive of political reality than are theories of Majoritarian Pluralism. It is simply not the case that a host of diverse, broadly-based interest groups take policy stands-and bring about actual policies- that reflect what the general public wants. Interest groups as a whole do not seek the same policies as average citizens do. "Potential groups" do not fill the gap. Relatively few mass-based interest groups are active, they do not (in the aggregate) represent the public very well, and they have less collective impact on policy than do business-oriented groups-whose stands tend to be negatively related to the preferences of average citizens. These business groups are far more numerous and active; they spend much more money; and they tend to get their way.

Table 4 also confirms our earlier findings about economic elites and median voters. When the alignments of business-oriented and mass-based interest groups are included separately in a multivariate model, average citizens' preferences continue to have essentially zero estimated impact upon policy change, while economic elites are still estimated to have a very large, positive, independent impact.

\section{American Democracy?}

Each of our four theoretical traditions (Majoritarian Electoral Democracy, Economic-Elite Domination, Majoritarian Interest-Group Pluralism, and Biased Pluralism) emphasizes different sets of actors as critical in determining U.S. policy outcomes, and each tradition has engendered a large empirical literature that seems to show a particular set of actors to be highly influential. Yet nearly all the empirical evidence has been essentially bivariate. Until very recently it has not been possible to test these theories against each other in a systematic, quantitative fashion.

By directly pitting the predictions of ideal-type theories against each other within a single statistical model (using a unique data set that includes imperfect but useful measures of the key independent variables for nearly two thousand policy issues), we have been able to produce some striking findings. One is the nearly total failure of "median voter" and other Majoritarian Electoral Democracy theories. When the preferences of economic elites and the stands of organized interest groups are controlled for, the preferences of the average American appear to have only a minuscule, near-zero, statistically non-significant impact upon public policy.

The failure of theories of Majoritarian Electoral Democracy is all the more striking because it goes against the likely effects of the limitations of our data. The preferences of ordinary citizens were measured more directly than our other independent variables, yet they are estimated to have the least effect. 
Nor do organized interest groups substitute for direct citizen influence, by embodying citizens' will and ensuring that their wishes prevail in the fashion postulated by theories of Majoritarian Pluralism. Interest groups do have substantial independent impacts on policy, and a few groups (particularly labor unions) represent average citizens' views reasonably well. But the interest-group system as a whole does not. Overall, net interest-group alignments are not significantly related to the preferences of average citizens. The net alignments of the most influential, business-oriented groups are negatively related to the average citizen's wishes. So existing interest groups do not serve effectively as transmission belts for the wishes of the populace as a whole. "Potential groups" do not take up the slack, either, since average citizens' preferences have little or no independent impact on policy after existing groups' stands are controlled for.

Furthermore, the preferences of economic elites (as measured by our proxy, the preferences of "affluent" citizens) have far more independent impact upon policy change than the preferences of average citizens do. To be sure, this does not mean that ordinary citizens always lose out; they fairly often get the policies they favor, but only because those policies happen also to be preferred by the economically-elite citizens who wield the actual influence.

Of course our findings speak most directly to the "first face" of power: the ability of actors to shape policy outcomes on contested issues. But they also reflect-to some degree, at least - the "second face" of power: the ability to shape the agenda of issues that policy makers consider. The set of policy alternatives that we analyze is considerably broader than the set discussed seriously by policy makers or brought to a vote in Congress, and our alternatives are (on average) more popular among the general public than among interest groups. Thus the fate of these policies can reflect policy makers' refusing to consider them rather than considering but rejecting them. (From our data we cannot distinguish between the two.) Our results speak less clearly to the "third face" of power: the ability of elites to shape the public's preferences. ${ }^{49} \mathrm{We}$ know that interest groups and policy makers themselves often devote considerable effort to shaping opinion. If they are successful, this might help explain the high correlation we find between elite and mass preferences. But it cannot have greatly inflated our estimate of average citizens' influence on policy making, which is near zero.

What do our findings say about democracy in America? They certainly constitute troubling news for advocates of "populistic" democracy, who want governments to respond primarily or exclusively to the policy preferences of their citizens. In the United States, our findings indicate, the majority does not rule — at least not in the causal sense of actually determining policy outcomes.
When a majority of citizens disagrees with economic elites or with organized interests, they generally lose. Moreover, because of the strong status quo bias built into the U.S. political system, even when fairly large majorities of Americans favor policy change, they generally do not get it.

A possible objection to populistic democracy is that average citizens are inattentive to politics and ignorant about public policy; why should we worry if their poorlyinformed preferences do not influence policy making? Perhaps economic elites and interest-group leaders enjoy greater policy expertise than the average citizen does. Perhaps they know better which policies will benefit everyone, and perhaps they seek the common good, rather than selfish ends, when deciding which policies to support.

But we tend to doubt it. We believe instead thatcollectively_ordinary citizens generally know their own values and interests pretty well, and that their expressed policy preferences are worthy of respect. ${ }^{50}$ Moreover, we are not so sure about the informational advantages of elites. Yes, detailed policy knowledge tends to rise with income and status. Surely wealthy Americans and corporate executives tend to know a lot about tax and regulatory policies that directly affect them. But how much do they know about the human impact of Social Security, Medicare, food stamps, or unemployment insurance, none of which is likely to be crucial to their own well-being? Most important, we see no reason to think that informational expertise is always accompanied by an inclination to transcend one's own interests or a determination to work for the common good.

All in all, we believe that the public is likely to be a more certain guardian of its own interests than any feasible alternative.

Leaving aside the difficult issue of divergent interests and motives, we would urge that the superior wisdom of economic elites or organized interest groups should not simply be assumed. It should be put to empirical test. New empirical research will be needed to pin down precisely who knows how much, and what, about which public policies.

Our findings also point toward the need to learn more about exactly which economic elites (the "merely affluent"? the top 1 percent? the top one-tenth of 1 percent?) have how much impact upon public policy, and to what ends they wield their influence. Similar questions arise about the precise extent of influence of particular sets of organized interest groups. And we need to know more about the policy preferences and the political influence of various actors not considered here, including political party activists, government officials, and other noneconomic elites. We hope that our work will encourage further exploration of these issues.

Despite the seemingly strong empirical support in previous studies for theories of majoritarian democracy, 
our analyses suggest that majorities of the American public actually have little influence over the policies our government adopts. Americans do enjoy many features central to democratic governance, such as regular elections, freedom of speech and association, and a widespread (if still contested) franchise. But we believe that if policymaking is dominated by powerful business organizations and a small number of affluent Americans, then America's claims to being a democratic society are seriously threatened.

\section{Notes}

1 Tocqueville 2000, 235-49. Tocqueville focused on state governments, which he said "really direct[ed]" American society; he noted that the Founders had imposed limits on direct democracy in the federal government $(235$, n. 1.) Yet he asserted in general terms that " $[\mathrm{t}]$ he laws of democracy . . . emanate from the majority of all citizens"; 222.

2 Lincoln 1863. Dahl 1956, ch. 2, defined "populistic democracy" in terms of pure majority rule and traced its theoretical roots to Aristotle's political equality, Locke's “majority power," Rousseau's "general will” of the majority, and James Madison's "republican principle," and critically analyzed its normative properties.

3 Hotelling 1929; Black 1948, 1958; Downs 1957. In his full-information ch. 2, Downs offers a clever though somewhat indeterminate non-dimensional version of the theory; in ch. 8 he explicates a variant of Hotelling's single-dimensional version. For extensions to multiple dimensions see Davis, Hinich, and Ordeshook 1970. May's Theorem establishes that simple majority rule is the only collective decision rule for choosing between two alternatives that satisfies the Arrow-type democratic conditions of decisiveness, anonymity, neutrality, and positive responsiveness to individuals' preferences; May 1952.

4 Arrow 1963, McKelvey 1976. See Sen 1970.

5 A particularly trenchant critique is given in Ferguson 1995 (Appendix: "Deduced and Abandoned").

6 Monroe 1979, 1998; Page and Shapiro 1983; Erikson, Wright, and McIver 1993; Stimson, MacKuen, and Erikson 1995; Erikson, MacKuen, and Stimson 2002.

7 Bartels 2008, Gilens 2012. See also Jacobs and Page 2005, which indicates that the general public may have little or no influence on U.S. foreign policy, when the preferences of business leaders and other elites are taken into account.

8 Key 1961, ch. 11 and 472-76; Fiorina 1981; Zaller 2003. A variant on this logic that focuses on the possibility of politicians "pandering" to current preferences under certain conditions is given in Canes-Wrone, Herron, and Shotts 2001. "Latent" preferences are the collective policy preferences that citizens would derive from their basic needs and values if they had accurate information about the future unfolding of policy results. Such "latent" preferences are related to the ideal, "authentic" preferences that some political theorists see as superior to, and more worthy of governmental responsiveness than, the policy preferences that citizens actually express. This can be seen as adding normative appeal to an electoralreward-and-punishment system of democratic control. See Mansbridge 2003.

9 See Page and Shapiro 1992.

10 Mills 1959, ch. 12, especially 279. Robert Michels 2001, a founder of modern elite theory, emphasized positions of leadership in political parties.

Some of Theda Skocpol's early work (e.g., Skocpol and Finegold 1982) can be seen as based on a state-centric elite theory that emphasizes public officials. Beginning with Protecting Soldiers and Mothers (1992), however, Skocpol's analyses of American politics have paid more attention to non-state elites, social movements, organized interest groups, and the preferences of the general public. Thus Skocpol's work, like that of a number of other important scholars of American politics (e.g., Katznelson 2013), does not fit neatly into our simple theoretical categories.

11 Beard 1913; Domhoff 2013; Burch 1980-1981; Ferguson 1995; Winters 2011; Winters and Page 2009. The boundary between elite theories that focus on economically-elite individuals, and interest group theories that focus on organized corporate interests (discussed later), is not always a sharp one. Here we treat most theories that emphasize corporate organizations or industrial sectors (e.g., Block 2007, Ferguson 1995) as primarily constituting "interest group" rather than elite theories. We categorize self-identified elite theorists like Domhoff as such even if they emphasize business elites and treat corporate organizations as important mechanisms of influence. Winters 2011 may come closest to an exclusive focus on wealthy individuals rather than organizations.

One might argue that the economic classes central to classical Marxist theories amount to "economic elites." But Marxist theorists see class position as only imperfectly related to wealth or income, and their focus on ownership of the means of production suggests that business firms and business associations may be the key political actors. Hence we will discuss these theories in connection with corporations and organized interest groups, noting the kinship of "instrumentalist” Marxist theories to theories of biased pluralism.

12 The term "interest group" tends to evoke images of membership groups like the League of Women Voters or the National Rifle Association, but many politically important "groups" are in fact business corporations.

13 Hamilton, Madison, and Jay 1961, 77-84.

14 Bentley 1908; Truman 1971, especially 511. 
15 Dahl 1956, 1989. Berry 1999 emphasizes the rising power of "citizen groups."

16 Olson 1965.

17 Schattschneider 1960, 35; Schlozman, Verba, and Brady 2012, ch. 10-14.

18 Schattschneider 1960, ch. 1; McConnell 1966; Stigler 1971; Lindblom 1977, parts IV and V; Ferguson 1995; Block 2007; Hacker and Pierson 2010.

19 Marx and Engels 1972. This English-language text comes from the 1888 publication edited by Engels.

20 Miliband 1969, ch. 6. Fred Block (1977) makes a critical distinction between "instrumentalist" Marxist theories like Miliband's, in which politically conscious members of ruling class use their economic resources to shape state action in their own material interests, and "structural" theories, in which the capitalist economic system itself tends to shape state policies and the preferences of its citizens-including workers, who are compelled to accept low wages and high capitalist profits for the sake of future investment and growth. On alternative Marxist theories of power, see also Isaac $1987 \mathrm{~b}$. For a formalized structural Marxist theory, see Przeworski and Wallerstein 1982.

21 Again, our data can do little to distinguish among these or other mechanisms of political influence. We focus on possible sources of influence among individuals and groups in society.

22 Schlozman, Verba, and Brady 2012, ch. 10-14, especially 321, 329, 356.

23 Schattschneider 1935.

24 Bauer, Pool, and Dexter 1963; Milbrath 1963; McChesney 1997.

25 Smith 2000; Baumgartner et al. 2009.

26 Smith 2000, ch. 3.

27 Numerical success rates are not reported in Smith 2000 , but the "enactment scorecard" line in figure 4.1 (83) appears to show Chamber success on 60 percent or more of the bills in most years, with very substantial variation from year to year.

28 Baumgartner et al. 2009, 233, 235. These multivariate results may be biased downwards because the regressions include as independent variables congressional and executive branch officials' active support for (or opposition to) policy changes. Since officials' behavior may well have been influenced by the interest groups themselves, the inclusion of these predictors restricts the estimates of group influence to direct effects, excluding any indirect impact that was channeled through interest groups' influence over officials. On the other hand, the omission of other influential actors from the analysis could (if their preferences were positively correlated with those of interest groups) produce spuriously inflated estimates of interest-group influence. A further complexity in assessing interestgroup influence involves policy cases in which groups take no stand at all, which are not included in the analysis by either Smith or Baumgartner et al. Inclusion of no-stand cases would be necessary if one sought to assess the extent to which groups affect overall policy results - though not for assessing the extent of group influence in the cases where influence attempts are actually made.

29 Appreciation for their fine work in assisting with the colossal task of collecting and coding these data goes to Marty Cohen, Jason Conwell, Andrea Vanacore, and Mark West at UCLA, and Oleg Bespalov, Daniel Cassino, Kevin Collins, Shana Gadarian, Raymond Hicks, and Lee Shaker at Princeton.

30 Arguments for the normative and empirical relevance of the "survey agenda" are discussed in Gilens 2012, 50-56. Note that if (as we find) the public has little or no influence on our issues, which tilt toward high salience, it is unlikely that the public has much influence on more technical or obscure matters.

31 In 2012, the tenth percentile of household income was about $\$ 12,200$, the fiftieth percentile about $\$ 51,000$, and the ninetieth percentile about $\$ 146,000$ (U.S. Census Bureau, 2013). For further detail on these data, see Gilens 2012, 57-66.

32 Of course the average (median) citizen is not identical to the eligible or actual "median voter." But the generally small magnitude of differences between the policy preferences of voters and those of all citizens (Wolfinger and Rosenstone 1980, 109-114; Schlozman, Verba, and Brady 2012, 120-21) suggests that our measure captures the spirit of median voter theories. To the extent that differences exist, we consider the average citizen to be of greater normative-though less empirical-importance.

33 To make an approximate assessment of the fit between the preferences of the median-preference respondent and those of the median-income respondent we calculated the median preference within each of five income groups (at the tenth, thirtieth, fiftieth, seventieth, and ninetieth percentiles). For example, if, on a particular non-monotonic item, the five income groups had imputed median preferences of .50, .60, .70 .65 and .55 (for the tenth to ninetieth income percentiles, respectively), then the estimated over-all median preference would be .60 (in this case equaling the preference at the thirtieth income percentile). In most cases the over-all median preference is the same as the median income (fiftieth percentile) preference. When it is not, the preference differences across income levels tend to be small. Using this technique, the median over-all preferences and the median-income preferences track each other very closely: $r=.997$.

34 This study is one of the few surveys that meets the two criteria of having a sufficiently large sample size $(n=20,150)$ and a high enough top-coded income 
category to provide information on the policy preferences of very affluent Americans.

35 Correlations of the policy preferences of the top 2 percent with those of the top 10 percent are based on the 76 CCES respondents who reported at least $\$ 350,000$ in family income. Using the 179 CCES respondents who reported at least $\$ 250,000$ (roughly the top 4.5 percent of the income distribution), the corresponding correlations are .97 and .76.

Some corroborating evidence comes from a comparison of the Survey of Economically Successful Americans (Page, Bartels, and Seawright 2013), based on a local sample of the wealthiest 1 percent or 2 percent of Americans, and the Inequality Survey (Page and Jacobs 2009), which was based on a representative sample of the American public. Eight policy-preference questions that were included on both surveys showed that the preferences of the top 25 percent of income earners generally fell about half way between those of the average citizen and those of the wealthy. For similar findings concerning the policy preferences of the top 4 percent or so of income earners, see Page and Hennessy 2008.

36 We distinguish conceptually between two sorts of deficiencies in our measures: flaws that affect the relationship between our indictors and their underlying concepts (such as the random and correlated measurement errors we discuss in the appendix), and flaws that arise from the imperfect fit between those concepts and the characteristics we would prefer to measure. For example, the adjustments described in the appendix help us to improve our estimates of the preferences of Americans at the ninetieth income percentile, but they cannot help to make those estimates any more accurate as indicators of the preferences of the truly rich Americans whose views we would prefer to include in our models.

37 Baumgartner et al. 2009, 225. We believe that our measure of net interest group alignment (described later) is actually superior to the Fortune 25 proxy examined by Baumgartner et al. because it includes industries that do not lobby through centralized trade organizations, it is nonlinear in net number of groups, and it reflects the extent to which a particular issue is central to the concerns of an interest group or industry.

38 For more detail on the Index of Net Interest Group Alignment, see Gilens 2012, 127-30.

39 On the measurement of policy change, see Gilens 2012 (60) and note 18 (284).

40 For correlations of individual groups' positions with average citizens' preferences see Gilens 2012, 156-57.

41 These particular values for low and high levels of support among affluent Americans and interest groups were chosen because about 15 percent of all proposed policy changes generated either less than 20 percent or more than 80 percent support among the affluent, and about fifteen percent of all proposed changes on which interests groups took a position generated a raw net interest group score of either more than five groups strongly in favor or more than five groups strongly opposed (counting "somewhat" favorable or opposed as one-half of a group).

42 See Monroe 1979, 1998; Page and Shapiro 1983; Stimson, MacKuen, and Erikson 1995.

43 Perhaps counterintuitively, it turns out that business groups tilted somewhat less toward opposing proposed changes (33 percent opposed, 26 percent in favor) than mass-based groups did (38 percent opposed, 20 percent in favor.)

44 Even if existing organized groups did not reflect the wishes of average citizens, officials' anticipated reactions to unformed "potential groups" might in theory provide some representation for average citizens, as David Truman argued they do. But our table 3 finding of negligible independent influence by average citizens when existing organized interest groups' positions are controlled for, leaves little room for potential groups (and officials' anticipation of them) to advance the preferences of ordinary citizens.

45 Schlozman, Verba, and Brady 2012, ch. 10-14, especially 321, 329, 356.

46 For the 369 out of 1,779 cases in which both businessbased and mass-based interest groups took a stand, the coefficients are just .09 (n.s.) for mass groups but $.48^{* *}$ $(\mathrm{p}<.001)$ for business groups.

47 For those proposed policy changes on which at least one business-oriented group took a position, another business-oriented group was found on the opposite side less than 5 percent of the time. Interestingly, mass-based groups were somewhat more likely to take stands on both sides of an issue, for example pro-life and pro-choice groups on abortion, or the AARP which opposed the Clinton health reform plan and the AFL-CIO that favored it.

48 For the analysis in table 4, both the business and mass interest group indices were scaled to run from 0 to 1 . When we rescaled these indices to reflect the differing numbers of business and mass-based groups engaged on each issue, the standard deviation of the business alignment index was .158 and the mass-oriented index .096; their associations with policy outcomes (analogous to those shown in table 4) were almost identical, at .38 $(\mathrm{p}<.01)$ and .40 $(\mathrm{p}<.001)$, respectively.

49 Bachrach and Baratz 1962, Lukes 1974. See Isaac $1987 \mathrm{a}$.

50 On the normative argument, see Dahl 1989, especially ch. 7. For empirical evidence that its conditions tend to be satisfied, see Page and Shapiro 1992 and Gilens 2011. 


\section{Supplementary Materials}

- Business- and Mass-Based Interest-Groups Included in Net Group Alignment Indices

- Correcting for Measurement Error

- Table A1. Ordinary least squares analysis parallel to the structural equation model presented in table 3.

- Data/code for replicating results http://dx.doi.org/ $10.1017 / S 1537592714001595$

\section{References}

Arrow, Kenneth J. 1963 [1951]. Social Choice and Individual Values. 2d ed. New York: Wiley.

Bachrach, Peter, and Morton S. Baratz. 1962. "Two Faces of Power." American Political Science Review 56(4): 947-52.

Bartels, Larry M. 2008. Unequal Democracy: The Political Economy of the New Gilded Age. New York: Russell Sage Foundation and Princeton University Press.

Bauer, Raymond A., Ithiel de Sola Pool, and Lewis Anthony Dexter. 1967. American Business and Public Policy: The Politics of Foreign Trade. New York: Atherton.

Baumgartner, Frank R., Jeffrey M. Berry, Marie Hojnacki, David C. Kimball, and Beth L. Leech. 2009. Lobbying and Policy Change: Who Wins, Who Loses, and Why. Chicago: University of Chicago Press.

Beard, Charles A. 2012 [1913]. An Economic Interpretation of the Constitution of the United States. New York, Simon and Schuster.

Bentley, Arthur F. 1908. The Process of Government: A Study of Social Pressures. Chicago, IL: University of Chicago Press.

Berry, Jeffrey M. 1999. The New Liberalism: The Rising Power of Citizen Groups. Washington, DC: Brookings.

Black, Duncan. 1948. "On the Rationale of Group Decision-making." Journal of Political Economy 56: $23-34$.

- 1958. The Theory of Committees and Elections. Cambridge: Cambridge University Press.

Block, Fred. 1977. "The Ruling Class Does Not Rule: Notes on the Marxist Theory of the State." Socialist Revolution 7(3): 6-28.

. 2007. "Understanding the Divergent Trajectories of the United States and Western Europe: A NeoPolanyian Analysis." Politics and Society (March): 1-31.

Burch, Philip H. 1980-81. Elites in American History. 3 vol. New York: Holmes \& Meier.

Canes-Wrone, Brandice, Michael C. Herron, and Kenneth W. Shotts. 2001. "Leadership and Pandering: A Theory of Executive Policymaking." American Journal of Political Science 45: 532-50.

Dahl, Robert A. 1956. A Preface to Democratic Theory. Chicago, IL: University of Chicago Press. 1961. Who Governs? New Haven, CT: Yale University Press.
1989. Democracy and its Critics. New Haven, CT: Yale University Press.

Davis, Otto A., Melvin J. Hinich, and Peter C. Ordeshook. 1970. "An Expository Development of a Mathematical Model of the Electoral Process." American Political Science Review 64(2): 426-48.

Domhoff, G. William. 2013. Who Rules America: The Triumph of the Corporate Rich. 7th ed. New York: McGraw-Hill.

Downs, Anthony. 1957. An Economic Theory of Democracy. New York: Harper \& Row.

Erikson, Robert S., Michael B. MacKuen, and James A. Stimson. 2002. The Macro Polity. New York: Cambridge University Press.

Erikson, Robert S., Gerald C. Wright, and John P. McIver. 1993. Statehouse Democracy: Public Opinion and Policy in the American States. New York: Cambridge University Press.

Ferguson, Thomas. 1995. Golden Rule: The Investment Theory of Party Competition and the Logic of MoneyDriven Political Systems. Chicago, IL: University of Chicago Press.

Fiorina, Morris. 1981. Retrospective Voting in American National Elections. New Haven, CT: Yale University Press.

Gilens, Martin. 2011. "Two-thirds Full? Citizen Competence and Democratic Governance." In New Directions in Public Opinion, ed. Adam Berinsky. New York: Routledge. . 2012. Affluence and Influence: Economic Inequality and Political Power in America. New York: Russell Sage Foundation and Princeton University Press.

Hacker, Jacob S., and Paul Pierson. 2010. Winner-TakeAll Politics: How Washington Made the Rich Richer-and Turned its Back on the Middle Class. New York: Simon $\&$ Schuster.

Hamilton, Alexander, James Madison, and John Jay. 1961 [1787-88]. The Federalist Papers, ed. Clinton Rossiter. New York: New American Library.

Hotelling, Harold. 1929. "Stability in Competition." Economic Journal 39: 41-57.

Isaac, Jeffrey. 1987a. "Beyond the Three Faces of Power: A Realist Critique." Polity 20(1): 4-31.

1987b. Power and Marxist Theory. Ithaca, NY: Cornell University Press.

Jacobs, Larry R., and Benjamin I. Page. 2005. "Who Influences U.S. Foreign Policy?” American Political Science Review 99(1): 107-23.

Katznelson, Ira. 2013. Fear Itself: The New Deal and the Origins of Our Time. New York: Liveright.

Key, V.O., Jr. 1961. Public Opinion and American Democracy. New York: Knopf.

Lindblom, Charles E. 1977. Politics and Markets. New York: Basic.

Lincoln, Abraham. 1989 [1863]. "Address at Gettysburg, Pennsylvania." In Speeches and Writings 1859-1865. New York: Library of America. 
Lukes, Steven. 1974. Power: A Radical View. London: Macmillan.

Mansbridge, Jane. 2003. "Rethinking Representation." American Political Science Review 97(4): 515-28.

Marx, Karl, and Friedrich Engels. 1972 [1848-1888]. Manifesto of the Communist Party. In The Marx-Engels Reader, ed. Robert C. Tucker. New York:

W.W. Norton. See also http://www.marxists.org/archive/ marx/works/1848/communist-manifesto/ch01.htm

May, Kenneth O. 1952. "A Set of Independent Necessary and Sufficient Conditions for Simple Majority Decisions." Econometrica 20: 680-84.

McChesney, Fred S. 1997. Money for Nothing: Politicians, Rent Extraction, and Political Extortion. Cambridge, MA: Harvard University Press.

McConnell, Grant. 1966. Private Power and American Democracy. New York: Random House.

McKelvey, Richard. 1976. " Intransitivities in Multidimensional Voting Models and Some Implications for Agenda Control." Journal of Economic Theory 12: 472-82.

Michels, Robert. 2001 [1911]. Political Parties: A Sociological Study of the Oligarchical Tendencies of Modern Democracy. Kitchener, Ontario: Batoche Books.

Milbrath, Lester W. 1963. The Washington Lobbyists. Chicago, IL: Rand-McNally.

Miliband, Ralph. 1969. The State in Capitalist Society. New York: Basic.

Mills, C. Wright. 1959 [1956]. The Power Elite. Galaxy edition. New York: Oxford University Press.

Monroe, Alan D. 1979. "Consistency between Public Preferences and National Policy Decisions." American Politics Quarterly 7: 3-18.

1998. "Public Opinion and Public Policy 19801993." Public Opinion Quarterly 68: 6-28.

Olson, Mancur, Jr. 1965. The Logic of Collective Action: Public Goods and the Theory of Groups. Cambridge, MA: Harvard University Press.

Page, Benjamin I., Larry M. Bartels, and Jason Seawright. 2013. "Democracy and the Policy Preferences of Wealthy Americans." Perspectives on Politics 11(1): 51-73.

Page, Benjamin I., and Cari Lynn Hennessy. 2008. "What Affluent Americans Want from Politics." WP-11-08. Institute for Policy Research, Northwestern University.

Page, Benjamin I., and Lawrence R. Jacobs. 2009. Class War? What Americans Really Think about Economic Inequality. Chicago, IL: University of Chicago Press.

Page, Benjamin I., and Robert Y. Shapiro. 1983. "Effects of Public Opinion on Policy." American Political Science Review 77(1): 175-90.

1992. The Rational Public: Fifty Years of Trends in Americans' Policy Preferences. Chicago, IL: University of Chicago Press.
Poole, Keith, and Howard Rosenthal. 2007. Ideology and Congress. New Brunswick, NJ: Transaction Publishers.

Przeworksi, Adam, and Michael Wallerstein. 1982. "The Structure of Class Conflict in Democratic Capitalist Societies." American Political Science Review 76(2): 215-38.

Schattschneider, E.E. 1935. Politics, Pressures and the Tariff. New York: Prentice-Hall. 1960. The Semi-Sovereign People: A Realist's View of Democracy in America. New York: Holt, Rinehart and Winston.

Schlozman, Kay Lehman, Sidney Verba, and Henry E. Brady. 2012. The Unheavenly Chorus: Unequal Political Voice and the Broken Promise of American Democracy. Princeton, NJ: Princeton University Press.

Sen, Amartya K. 1970. Collective Choice and Social Welfare. San Francisco, CA: Holden-Day.

Skocpol, Theda. 1992. Protecting Soldiers and Mothers: The Political Origins of Social Policy in the United States. Cambridge, MA: Harvard University Press.

Skocpol, Theda, and Kenneth Finegold. 1982. "State Capacity and Economic Intervention in the Early New Deal.” Political Science Quarterly 97: 255-78.

Smith, Mark A. 2000. American Business and Political Power: Public Opinion, Elections, and Democracy. Chicago, IL: University of Chicago Press.

Stigler, George J. 1971. "The Theory of Economic Regulation." The Bell Journal of Economics and Management Science 2(1): 3-21.

Stimson, James A., Michael B. MacKuen, and Robert S. Erikson. 1995. "Dynamic Representation.” American Political Science Review 89(3): 543-65.

Tocqueville, Alexis de. 2000 [1835-1840]. Democracy in America. Trans. and ed. Harvey C. Mansfield and Delba Winthrop. Chicago, IL: University of Chicago Press.

Truman, David B. 1971 [1951]. The Governmental Process. 2d. ed. New York: Alfred A. Knopf.

U.S. Census Bureau, 2013. "Income, Poverty, and Health Insurance Coverage: 2012” (September). Available at http://www.census.gov/newsroom/releases/pdf/ 20130917_ip_slides_with_plotpoints.pdf.

Winters, Jeffrey A. 2011. Oligarchy. New York: Cambridge University Press.

Winters, Jeffrey A., and Benjamin I. Page. 2009. "Oligarchy in the United States?" Perspectives on Politics 7(4): 731-51.

Wolfinger, Raymond E., and Steven J. Rosenstone. 1980. Who Votes? New Haven, CT: Yale University Press.

Zaller, John. 2003. "Coming to Terms with V.O. Key's Concept of Latent Opinion.” In Electoral Democracy, ed. Michael B. MacKuen and George Rabinowitz. Ann Arbor: University of Michigan Press. 